\title{
The effects of leptin on F-actin remodelling in type 1 diabetes
}

\author{
C. Guven ${ }^{1}$, E. Taskin¹, H. Akcakaya², R. Nurten² \\ ${ }^{1}$ Nigde Omer Halisdemir University, Turkey \\ 2Istanbul University, Turkey
}

[Received: 27 July 2018; Accepted: 11 September 2018]

Background: The aim of the current study is to investigate the effect of leptin on cytoskeleton structures in both in vivo and in vitro model of diabetes.

Materials and methods: For in vivo studies, leptin in different doses (240, and $480 \mathrm{mg} / \mathrm{kg}$ ) was injected to the diabetic rats after 1-week of streptozotocin (STZ, $55 \mathrm{mg} / \mathrm{kg}$ ) treatment. Leptin levels were analysed in serum, liver, and pancreas samples. Hepatic and pancreatic $F$ - and $G$-actin expressions were determined by Western blotting. For in vitro studies, hepatic and pancreatic primary cell lines were obtained from the control rats. To these cultures, STZ (15 and $30 \mathrm{mM})$, leptin (50, 60 and $100 \mathrm{ng} / \mathrm{mL}$ ), and their combinations were applied for 1, 3, and 4 weeks. After the treatment period, F-actin was visualised by the Alexa-fluor fluorescent dye.

Results: Streptozotocin decreased the G-actin in both tissues in vivo. However, leptin caused a dose-dependent increase in G-actin levels while F-actin decreased in both tissues. Moreover, leptin caused the perimembranous condensation of actin filaments and amelioration of F-actin structures in vivo. A dose-dependent corruption of F-actin filament structures was observed in leptin-treated primary cells in vitro, while STZ also caused corruption of these filaments. Co-exposure of STZ and leptin caused the amelioration of F-actin filaments, while the perimembranous condensation was also observed as was in vivo study.

Conclusions: Leptin therapy could be a candidate for diabetes, but it should not be ruled out as being important the severity of diabetes and leptin doses. (Folia Morphol 2019; 78, 2: 314-324)

Key words: cytoskeleton, diabetes, F-actin, G-actin, hepatic cells, pancreatic $\beta$-cells, leptin therapy

\section{INTRODUCTION}

Diabetes mellitus (DM) is one of common disease worldwide. In 2014, it was reported that $7.5 \%$ of women and $5 \%$ of men face to DM. The prevalence is expected to reach 439 million by 2030 meaning of total $7.7 \%$ adult population between 20 and 79 years [43]. There are two types of DM. One of this called type 1 associated with the increased blood glucose due to insufficient production of insulin in the body. Insulin insensitivity of the cells causes type 2 , and the body produces sufficient insulin in this cases. Therefore, it is essential to find effective strategies to manage or control the prevalence of DM. Herein, leptin takes great attention in the control

Address for correspondence: Dr. C. Guven, Niğde Ömer Halisdemir University, Medicine Faculty, Biophysics Department, Niğde, Turkey, e-mail:cgven@yahoo.com 
of hyperglycaemia and/or hyperglycemia-induced dysfunctions.

Leptin, a protein hormone, affects the body weight, energy metabolism, reproductive system, and the neuroendocrine system [24]. Furthermore, the hormone plays a significant role in insulin-glucose homeostasis in the pancreas, liver, muscle, and hypothalamus as well. Insulin stimulates leptin secretion [38]. Leptin has acted centrally in the hypothalamus and peripherally in the pancreas, muscle, and liver. Leptin also improves glucose-insulin metabolism via attenuating glycemia, insulinemia, and insulin resistance

To develop leptin-based therapies against diabetes, and other insulin resistance syndromes, leptin' effect on the glucose-insulin homeostasis should be understood well [38]. There is a complicated relationship between insulin resistance and leptin. For example, leptin may increase insulin sensitivity and improve the glucose metabolism [38]. Also, a previous study indicated that insulin resistance was ameliorated by administration of leptin in mice [6]. Hence, it was proposed that the leptin plays a possible role in insulin resistance and it can improve insulin production [6]. Insulin resistance can be described as insufficiency in the insulin pathway at target tissues which generally response, like adipose, liver, skeletal, and heart muscle [2].

The cytoskeleton is essential to keep cell shape and signalling pathways for the beta $(\beta)$ cells. The perturbation of actin structures might give rise to enhance $\beta$ cell dysfunction, including inflammation and fibrosis [1]. Actin plays a vital function in morphology, migration, adhesion, and permeability [33]. Actin is abundant and highly conserved proteins among species. It is a member of structural superfamily sugar kinases hexokinases and Hsp70 proteins [10]. Actin is one of the cytoskeleton element and has many essential roles in cells such as cell shape, polarity, endocytosis, contractility, motility, intracellular trafficking, etc. Actin has two form of monomeric $\mathrm{G}$-actin and filamentous polymeric F-actin [46]. G-actin can be converted to F-actin by the presence of adenosine three phosphate (ATP), ions, actin-binding proteins. F-actin and myosin interaction cause muscle contraction. The primary control factor of transformation is nucleotide hydrolysis [10]. Conversion of $\mathrm{G}$-actin to the filamentous form participates in pathological processes, such as cancer metastasis as well [50]

There is little knowledge available on the relationship between insulin and leptin. The current study was aimed to evaluate how F-actin structure can be affected by leptin therapy in streptozotocin (STZ)-induced diabetic rats in both in vivo and in vitro conditions. To our knowledge, it is the first study to investigate the effects of leptin on cytoskeleton structures of the STZ-treated cells and animals.

\section{MATERIALS AND METHODS}

\section{Experimental animals}

Male Wistar rats weighing between 140 and $250 \mathrm{~g}$ were purchased from the Faculty of Veterinary Medicine, Department of Reproduction and Artificial Insemination, Istanbul University. The animals were individually housed in stainless cages at $20 \pm 2^{\circ} \mathrm{C}$, $60-70 \%$ humidity with $12: 12 \mathrm{~h}$ photoperiod. Water and food were given ad libitum. All processes were approved by the Istanbul University Animal Welfare Committee.

\section{Induction of experimental diabetes}

Diabetes was induced by STZ. Streptozotocin was freshly prepared in a citrate buffer $(50 \mathrm{mM}, \mathrm{pH} 4.5)$. Control group received only citrate buffer as a vehicle. $55 \mathrm{mg} / \mathrm{kg}$ of STZ was injected the intraperitoneally to rats [42]. One week after STZ injection, animal having blood glucose levels $\geq 250 \mathrm{mg} / \mathrm{dL}$ was accepted as diabetic [27]. The blood glucose levels were measured by using a glucometer (OneTouch Ultra; LifeScan, Milpitas, CA, USA) from orbital vein blood samples.

\section{In vivo experimental design}

Four groups were randomly carried out as (I) control (C group): non-diabetic rats treated with the vehicle, (II) diabetes (D group): diabetic rats treated with the vehicle, (III) diabetes+leptin 240 (DL240 group): diabetic rats treated with $240 \mathrm{ng} /$ $\mathrm{kg}$ dose of leptin, (IV) diabetes+leptin 480 (DL480 group): diabetic rats treated with $480 \mathrm{ng} / \mathrm{kg}$ dose of leptin (modified from [47]). Both doses are physiologic doses of leptin [31]. Experimental animals were treated with the leptin every other day for 1 week. $C$ group received intraperitoneally physiological saline as the same volume of DL group. Four experimental animals were used for each group. After treatments periods, liver and pancreas were removed from experimental animals for $\mathrm{F}$ - and $\mathrm{G}$-actin analysis by Western blotting. Body weights were measured at two time points: at the beginning of the first injection and $24 \mathrm{~h}$ after the last injection. Then, body weight gain was calculated by subtracting from the last day to the first day of the experiment. 


\section{In vitro experimental design}

For in vitro studies, primary hepatic (modified from [28]) and pancreatic cells (modified from [21]) were isolated from the corresponding tissues of the $C$ group. Hepatic primary cells were recognised as parenchyma and Kupffer. The liver was removed aseptically and washed with Hanks' balanced salt solution (HBSS). Then, the tissues were minced into $1-\mathrm{mm}^{3}$ pieces in HBSS. The cells were suspended in William's Medium E (WME) and centrifuged for $5 \mathrm{~min}$ at $3000 \mathrm{~g}$ and the supernatant discarded. Cells were dissolved in WME and transferred into an incubator with $5 \% \mathrm{CO}_{2}$ atmosphere at $37^{\circ} \mathrm{C}$. For pancreatic acinar primary cell culture, each pancreas was minced into $1 \mathrm{~mm}^{3}$ piece and incubated with $2 \mathrm{~mL}$ of HBSS with $2 \mathrm{M}$ EDTA at $37^{\circ} \mathrm{C}$ for $15 \mathrm{~min}$. The chelated mixture was centrifuged for $5 \mathrm{~min}$ at $3000 \mathrm{~g}$, and the supernatant was discarded. The pellet was rinsed with $10 \mathrm{~mL}$ Ham's F-12 medium, centrifuged for $5 \mathrm{~min}$ at $3000 \mathrm{~g}$, and the supernatant discarded. The tissue pellet digested with $10 \mathrm{~mL}$ of $1 \mathrm{mg} / \mathrm{mL}$ collagenase type II, $1 \mathrm{mg} / \mathrm{mL}$ hyaluronidase and $20 \%$ heat-inactivated calf serum in Ham's F-12 medium at $37^{\circ} \mathrm{C}$ for $30 \mathrm{~min}$ in a shaking water bath. Following centrifugation at $3000 \mathrm{~g}$ for $5 \mathrm{~min}$, the supernatant discarded, pellet rinsed with $10 \mathrm{~mL}$ of HBSS, and this procedure was replicated. The cells were rinsed with $5 \%$ heat-inactivated calf serum in Ham's F-12 medium and centrifuged at $3000 \mathrm{~g}$ for $10 \mathrm{~min}$. The pellet rinsed with $10 \mathrm{~mL}$ of $5 \%$ heatinactivated calf serum in Ham's F-12. Cells allocated to a well containing $2 \mathrm{~mL}$ of Waymouth's serum-free medium and incubated at $37^{\circ} \mathrm{C}$ with $5 \%$ humidified $\mathrm{CO}_{2}$ for $48 \mathrm{~h}$.

The hepatic and pancreatic cells from non-diabetic control rats were divided into four groups as control (c group), STZ (S group), leptin (L group), and STZ+leptin (SL group) for 1 and 4 weeks. Like hepatic cells, the pancreatic cells were also divided into four groups. To observe the effect of severity of hyperglycaemia, the cell lines were treated with two different doses of STZ as 15 or $30 \mathrm{mM}$. To determine the effect of different doses of leptin on cell lines, 50,60 and $100 \mathrm{ng} / \mathrm{mg}$ of leptin were injected into the cells. The hepatic cells were treated with the leptin for 1 and 4 weeks. The pancreatic cells were treated with the leptin for 3 weeks. The data from DL groups in the pancreatic cells were not obtained because of lower cell numbers although the medium was replaced 2 times a week.

\section{F-actin organisation}

Immunofluorescence microscopy was used to determine F-actin organisation in both in vitro (the primary cell cultures) and in vivo (cryosections of liver and pancreas) [17]. Briefly, primary culture cells were fixed with $4 \%$ paraformaldehyde in phosphatebuffered saline (PBS) for $10 \mathrm{~min}$ at room temperature and then permeabilised and blocked in PBS containing $0.1 \%$ Triton $\mathrm{X}-100$ and $5 \%$ foetal calf serum for $30 \mathrm{~min}$. Actin filaments were visualised using rhodamine-phalloidin or Alexa 497, and nuclei were labeled with 4',6-diamidino-2-phenylindole dichloride (DAPI) (Invitro Molecular Probes, OR, USA). All images were obtained using an Olympus BX51 Microscope equipped with a DP72 camera controlled by Olympus DP2-TWAIN software.

\section{Western blotting}

In vivo, $\mathrm{F}$ - and G-actin proteins were isolated from the pancreas and liver tissues. Tissues were homogenised by a MagNA lyser (Roche Diagnostics). Aliquots of liver and pancreas homogenates were centrifuged at $3000 \mathrm{~g}$ for $15 \mathrm{~min}$ and $4500 \mathrm{~g}$ for $20 \mathrm{~min}$, respectively. F- and G-actin were separated by a kit (Cytoskeleton, Cat \#BK037) according to the manufacturer's instruction [26]. Then, $50 \mu \mathrm{g}$ F- or G-actin were loaded to SDS-PAGE and transferred to a PVDF membrane (Millipore Corporation, Bedford, MA, USA) at $100 \mathrm{~V}$ for $45 \mathrm{~min}$. The membranes were blocked by using $5 \%$ bovine serum albumin. Membranes were incubated with antiactin rabbit polyclonal antibody $(1 / 500)$ at $+4^{\circ} \mathrm{C}$ for overnight (Abcam, USA), and then incubated with a horseradish peroxidase-conjugated goat antirabbit IgG antibody for $1 \mathrm{~h}$ at room temperature. 5-bromo-chloro-3-indol phosphate (BCIP) was used for visualisation for protein band. After membranes were photographed with Canon camera, ImageJ was used to analyse the band.

\section{Leptin analysing}

Blood and homogenates of liver and pancreas were centrifuged at $10,000 \mathrm{~g}$ for $15 \mathrm{~min}$ at $+4^{\circ} \mathrm{C}$. Leptin levels were measured by ELISA using a commercial assay kit according to the manufacturer's directions (Millipore, USA) [7].

\section{Statistical analysis}

The analyses of statistical were performed by SPSS version 23.0. Data are expressed as mean \pm standard 
error of the mean (SEM). One-way analysis of variance (one-way ANOVA) with post hoc Tukey for equal variance assumed and post hoc Dunnett' $T 3$ for equal variance not assumed were used to compare mean between the groups. $\mathrm{P}<0.05$ was accepted as the statistical significance.

\section{RESULTS}

\section{Effect of leptin on body weight and blood} glucose level

Diabetes decreased significantly body weight gain in $D$ groups when compared to the $C$ group $(p<0.05)$. The treatment of leptin failed to control body weight gain in diabetic rats. Interestingly, $240 \mathrm{ng} / \mathrm{kg}$ of leptin non-significantly worsen the body weight gain in DL240 group compared to the D group. But, there were no significant differences in body weight gain among D, DL240, and DL480 groups (Fig. 1).

Blood glucose level is a primary parameter to determine diabetes. The delta was calculated by subtraction of glucose levels before and after experiments. As expected, all diabetes groups had high blood glucose level and the delta compared to $C$ group after STZ injection $(p<0.05)$. Leptin treatment did not improve the high blood glucose when compared to $D$ group (Fig. 2).

The leptin levels were measured in serum, liver and pancreas samples. Diabetes did not influence the leptin levels in serum, pancreas, and liver in contrast to $C$ group. Also, leptin treatment in all dose significantly increased the serum leptin levels compared to $D$ group as expected $(p<0.01)$. The doses of leptin higher than $240 \mathrm{ng} / \mathrm{kg}$ significantly increased the serum leptin levels in contrast to $D$ and DL240 groups $(p<0.01)$. However, the treatment of diabetic rats with leptin did not affect the level of leptin in liver and pancreas when compared to D group (Fig. 3).

\section{The effect of leptin on actin structure}

The actin structure is so crucial for glucose metabolism. Therefore, it was evaluated the F-actin distribution of liver and pancreas tissues in vivo and pancreas primary acinar, Kupffer and parenchymal also called as hepatocyte cells in vitro, as well.

For in vivo studies, diabetes induction gave rise to disrupt $\mathrm{F}$-actin structure in liver tissues. The treatment of diabetic rats with $240 \mathrm{ng} / \mathrm{kg}$ dose of leptin improved F-actin in DL240 group when compared to D group; however, as the dose of leptin $(480 \mathrm{ng} / \mathrm{kg}$, DL480) increases, it worsens the effect of diabetes

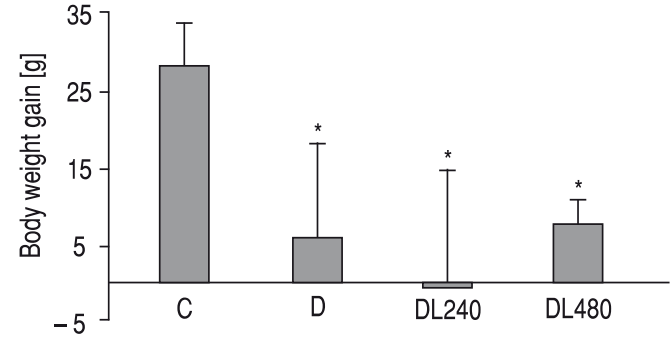

Figure 1. Body weight gain; C - control; D — diabetes; DL240 — diabetic rats treated with $240 \mathrm{ng} / \mathrm{kg}$ dose of leptin; DL480 — diabetic rats treated with $480 \mathrm{ng} / \mathrm{kg}$ dose of leptin; ${ }^{*} \mathrm{p}<0.01$; different from $\mathrm{C}$ group.

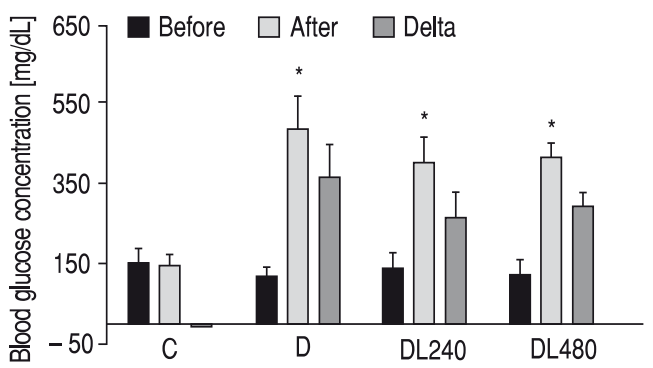

Figure 2. Blood glucose level; C - control; D - diabetes; DL240 — diabetic rats treated with $240 \mathrm{ng} / \mathrm{kg}$ dose of leptin; DL480 — diabetic rats treated with $480 \mathrm{ng} / \mathrm{kg}$ dose of leptin; ${ }^{*} \mathrm{p}<0.01$; different from $\mathrm{C}$ group.

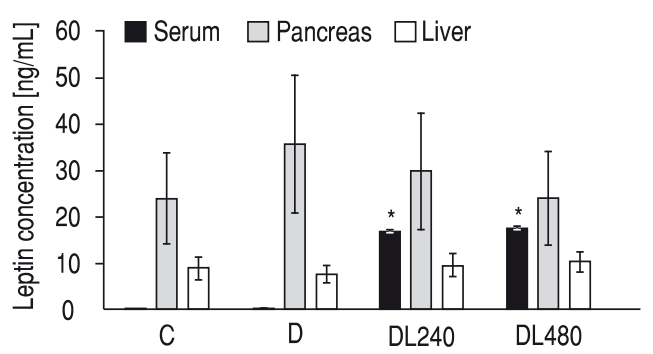

Figure 3. Leptin levels in serum, pancreas, and liver; $\mathrm{C}$ - control; D - diabetes; DL240 — diabetic rats treated with $240 \mathrm{ng} / \mathrm{kg}$ dose of leptin; DL480 - diabetic rats treated with $480 \mathrm{ng} / \mathrm{kg}$ dose of leptin; ${ }^{*} \mathrm{p}<0.01$; different from $\mathrm{D}$ group.

on F-actin (Fig. 4A-D). In pancreatic tissue, while diabetes also has a destructive impact on the F-actin structure in $D$ group compared to $C$ group, the leptin treatment in all doses had the protective effect on F-actin structure compared to D group (Fig. 4E-H). To evaluate the effect of leptin treatment on different cell types, parenchymal and Kupffer cells were also isolated from rats in C, D and DL240 groups. Based on cell types, the effects of leptin on F-actin 

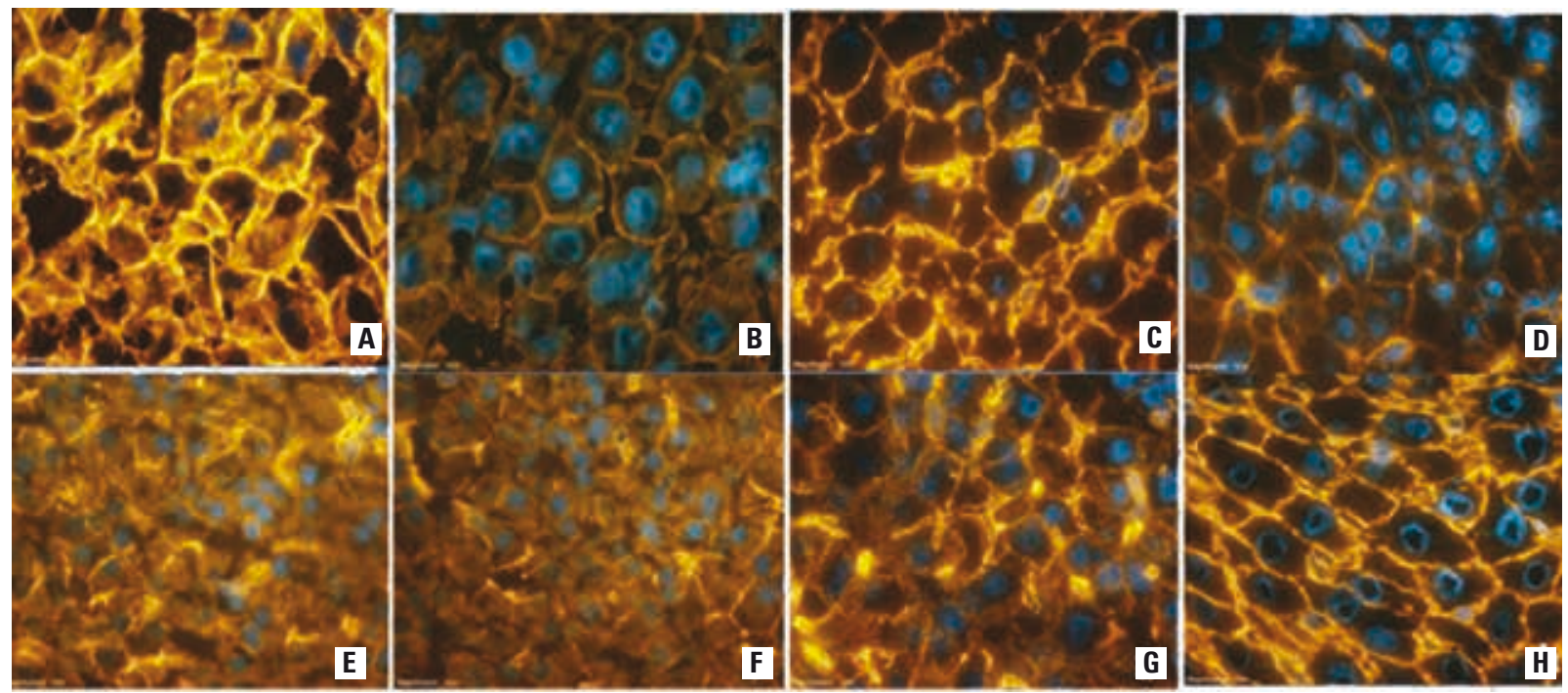

Figure 4. The leptin effect on F-actin distribution from liver and pancreas tissues; liver tissues were as from $\mathbf{A}$ to $\mathbf{D}$, although pancreas tissues were from E to H; A and E. Control; B and F. Diabetes; C and G. Diabetic rats treated with $240 \mathrm{ng} / \mathrm{kg}$ dose of leptin; D and $\mathbf{H}$. Diabetic rats treated with $480 \mathrm{ng} / \mathrm{kg}$ dose of leptin.

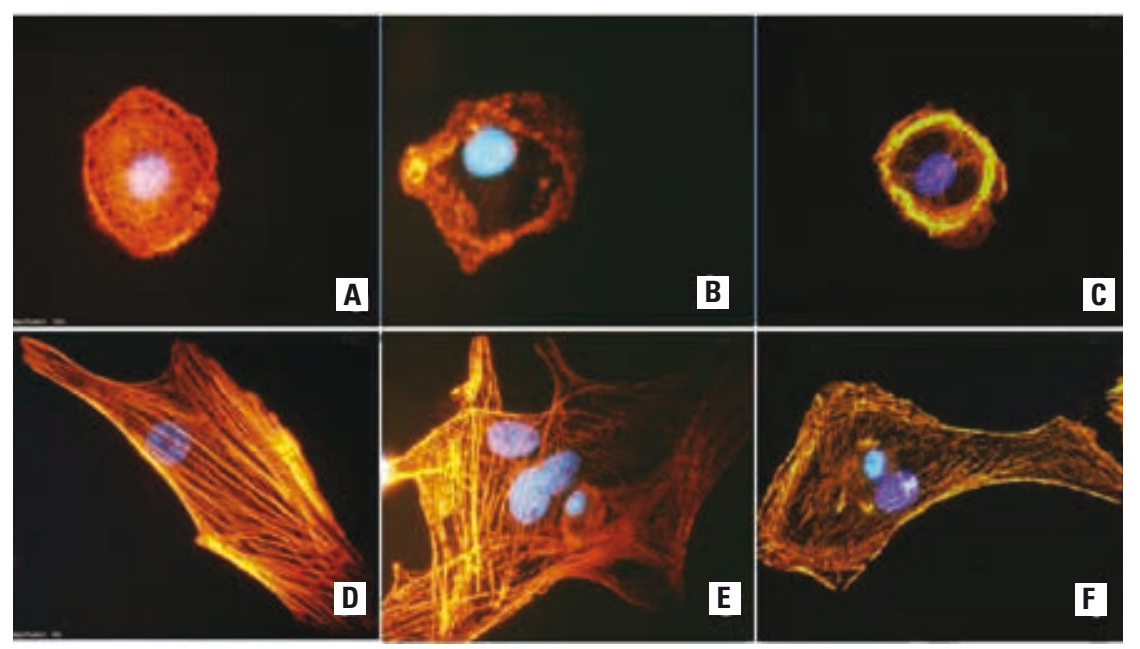

Figure 5. F-actin distribution of primary liver cells at parenchymal (upper line) and Kupffer cells (below line); red colour represents F-actin, blue represents the nucleus by DAPI at $\times 100$ magnification. Parenchymal cells: $\mathbf{A}$ and $\mathbf{D}$. Control; $\mathbf{B}$ and $\mathbf{E}$. Diabetes; $\mathbf{C}$ and $\mathbf{F}$. Diabetic rats treated with $240 \mathrm{ng} / \mathrm{kg}$ dose of leptin.

showed differences. In the parenchymal cells, F-actin disappeared in the cytosol (Fig. 5B, C) whereas slight destruction was observed in Kupffer cells (Fig. 5E, F).

Isolated primary cell cultures were preferred to reduce the number of animals used in the experiment. In primary liver cells, only $100 \mathrm{ng} / \mathrm{mL}$ dose of leptin (higher dose) was destructive on F-actin structure (Fig. 6G-I); therefore, the treatment of the cell with the leptin was not continued after 3 weeks. When compared to $100 \mathrm{ng} / \mathrm{mL}$ dose of leptin, $50 \mathrm{ng} / \mathrm{mL}$ dose of leptin was not so destructive to the F-actin structure in the isolated liver cells. In pancreas cells, the detrimental effect of leptin on F-actin was only observed at the dose of $60 \mathrm{ng} / \mathrm{mL}$ (Fig. 7C, D). In the present study, the effect of leptin on F-actin structure in STZ-induced pancreatic cells (SL group) were not evaluated due to high toxicity of STZ on pancreatic cells (Fig. 7E, F) because the cells were exposed to STZ at the beginning of the study and F-actin destruction was measured after three and/or 4 weeks. That indicates the highly destructive effects of STZ on the pancreas. 

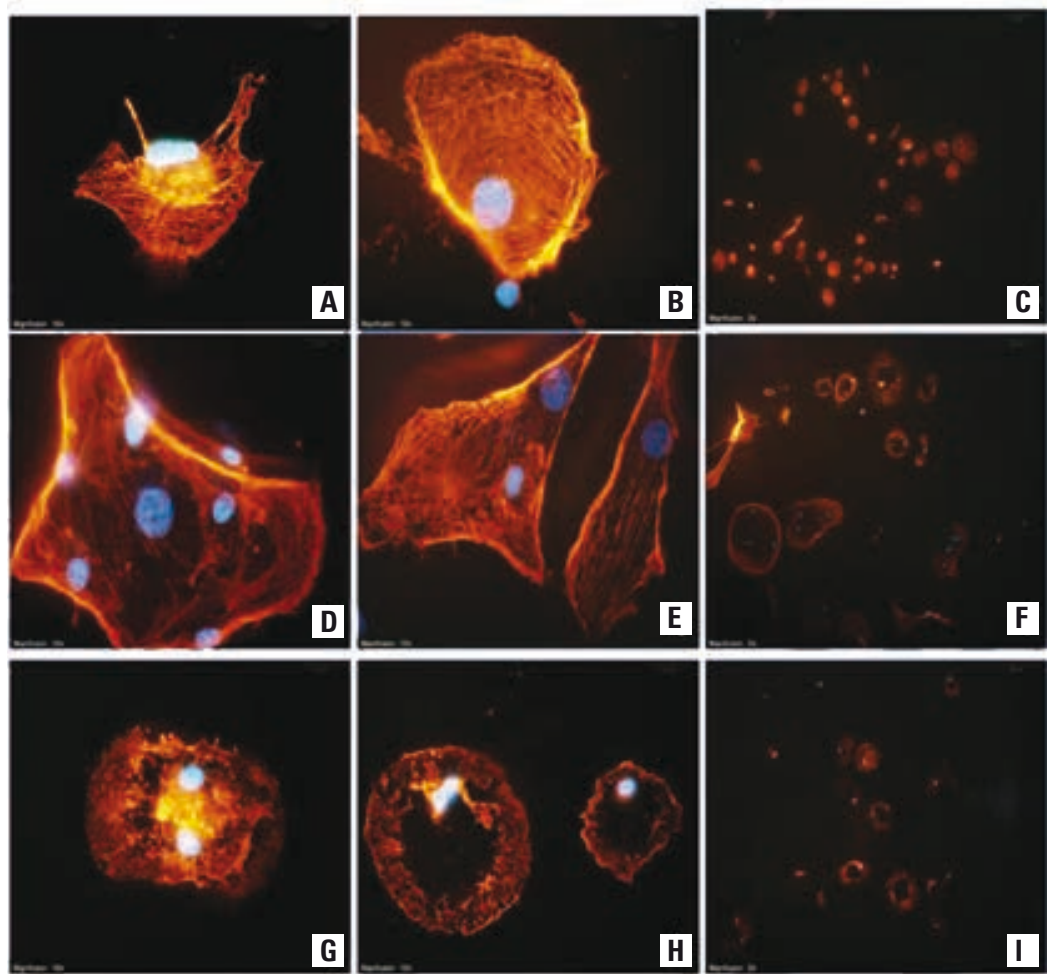

Figure 6. The leptin effect on F-actin distribution after 3 weeks treated on primary liver cells; A, B, C. Control; D, E, F. Cells treated with $50 \mathrm{ng} / \mathrm{mL}$ dose of leptin; G, H, I. Cells treated with $100 \mathrm{ng} / \mathrm{mL}$ dose of leptin (Panels C, F, I is at 20 magnification, and the other is at 100 magnification).
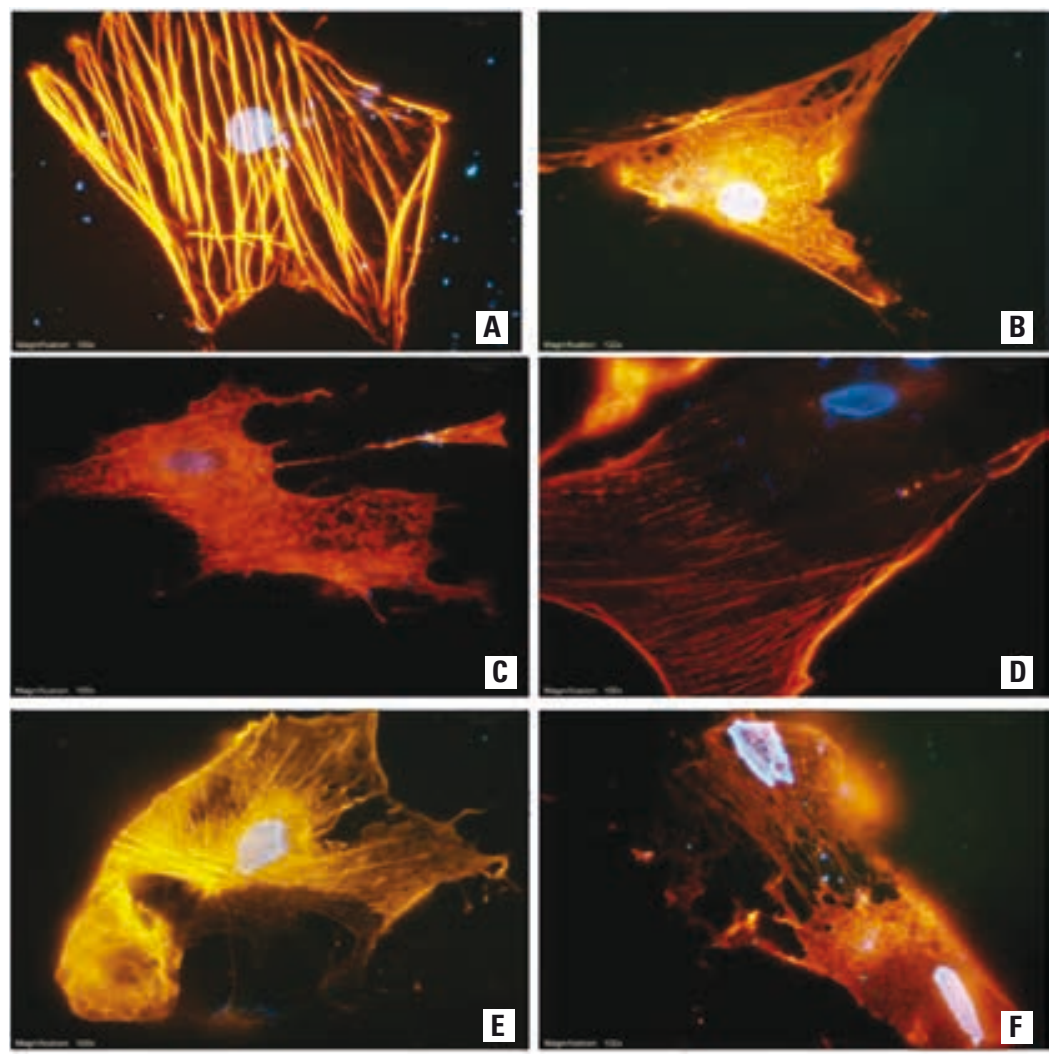

Figure 7. The leptin effect on F-actin distribution at primary pancreas cells at 100 magnification; A, B. Control; C, D. Cells treated with $60 \mathrm{ng} / \mathrm{mL}$ dose of leptin; $\mathbf{E}$, F. Cells treated with 30 doses of $\mathrm{mM}$ streptozotocin (magnification $\times 100$ ). 

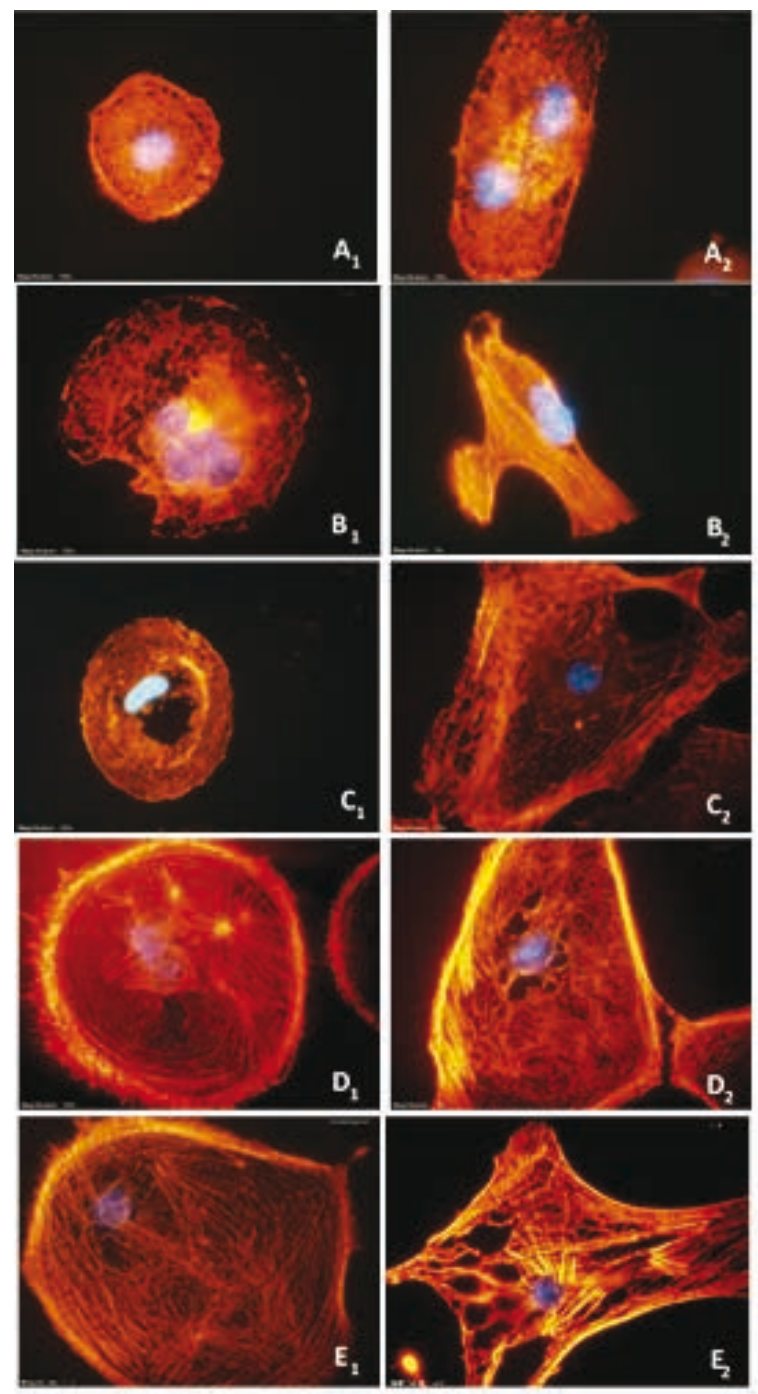

Figure 8. The leptin effect on $F$-actin distribution at parenchymal $\left(A_{1}, B_{1}, C_{1}, D_{1}, E_{1}\right)$ and Kupffer $\left(A_{2}, B_{2}, C_{2}, D_{2}, E_{2}\right)$ cells after 4 weeks treatment; $\mathbf{A}_{1}, \mathbf{A}_{2}$. Control; $\mathbf{B}_{1}, \mathbf{B}_{2}$. Cells treated with $15 \mathrm{mM}$ of streptozotocin; $\mathbf{C}_{1}, \mathbf{C}_{2}$. Cells treated with $30 \mathrm{mM}$ of streptozotocin, $\mathbf{D}_{1}$ and $\left.\mathbf{D}_{2}\right) 15 \mathrm{mM}$ exposed cells treated with $60 \mathrm{ng}$ leptin $E_{1}$ and $\left.E_{2}\right) 30 \mathrm{mM}$ exposed cells treated with $60 \mathrm{ng}$ leptin.
Also, the effects of leptin on F-actin structures in the primary hepatic cells were studied based on the severity of hyperglycaemia or diabetic condition. At the mild diabetic condition (15 mM STZ), filopodia formation by hyperglycaemia (Fig. 8B1, 8B2) was reversed by leptin treatment without any protection on the F-actin structure after 4 weeks in both at parenchymal and Kupffer (Fig. 8D1, 8D2). Leptin failed to improve $F$ destruction and filopodia formation (Fig. 8E1, 8E2); both induced by severe diabetic condition (30 mM STZ; Fig. 8C1, 8C2).

\section{The effect of leptin treatment on F- and G-actin protein expression}

Leptin treatment showed a protective effect on disproportional F- and G-actin protein expressions compared to diabetes groups in both liver and pancreas tissues in vivo (Fig. 9A-D).

\section{DISCUSSION}

Cytoskeleton plays a vital role in the cell morphology and the elasticity [14]. Insulin can tonically regulate actin filament network and microtubule as well $[35,51]$. Actin network mediates glucose transport through insulin action [51]. Actin phosphorylation alters cytoskeleton re-orientation via polymerisation and depolymerisation [14]. Insulin stimulates leptin secretion [38]. Leptin is considered as an anti-diabetic hormone. It plays a significant role in glucose homeostasis in the pancreas, liver, muscle, and hypothalamus. Also, it blocks glucose production in the liver and enhances glucose consumption in the tissue [37]. It was reported that the effects of leptin were mediated via the JAK/STAT signalling pathways. $\beta$-cells are hyperpolarised via ATP sensitive potassium chan-

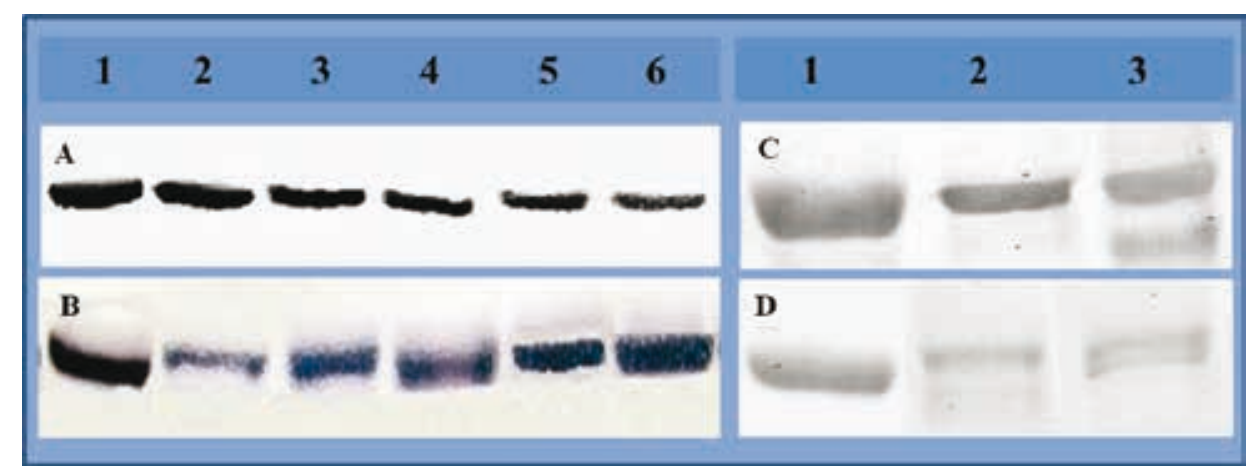

Figure 9. The alternation of F- and G-actin protein expression in pancreas and liver tissue; 1. Control; 2. Diabetes; 3. Diabetic rats treated with $240 \mathrm{ng} / \mathrm{kg}$ dose of leptin; 4 . Diabetic rats treated with $480 \mathrm{ng} / \mathrm{kg}$ dose of leptin; 5 . Diabetic rats treated with $720 \mathrm{ng} / \mathrm{kg}$ dose of leptin; 6. Diabetic rats treated with $960 \mathrm{ng} / \mathrm{kg}$ dose of leptin; A. F-actin of the liver; B. G-actin of the liver; C. F-actin of the pancreas; D. G-actin of the pancreas. 
nel $\left(\mathrm{K}_{\text {ATP }}\right)$ opening by leptin; actin cytoskeleton reorganises through the PI3K pathway [34]. STZ causes hyperphagia, hyperleptinaemia, hypoinsulinaemia, and hyperglycaemia [40]. Insulin can secrete leptin from adipose tissue, controversy; leptin suppresses insulin secretion from pancreatic $\beta$-cells by activation of $\mathrm{K}_{\text {ATP }}$ Leptin is reported to increase $\mathrm{K}_{\text {ATP }}$ trafficking to enhance the channel density on the membrane by strengthening F-actin depolymerisation. The trafficking of $\mathrm{K}_{\text {ATP }}$ by leptin is mediated through AMPK and protein kinases-A (PKA) [4].

In the present study, diabetes did not affect the serum, liver and pancreatic leptin levels. However, leptin treatment elevated only the serum leptin levels in diabetic rats without altering the pancreatic and liver levels. Our results are an inconsistency with the previous study, which indicates that increased plasma insulin levels due to increased insulin resistance could elevate the pancreatic leptin levels [41]. The result of the present study demonstrates that leptin did not improve blood glucose level in diabetes. Inconsistently, it was reported that a high dose of leptin ameliorated the both of hyperlipidaemia and hyperglycaemia [11, 20]. Co-treatment of leptin and insulin could be more useful to prevent hyperglycaemia than insulin only therapy, which reduces blood glucose to undesirable levels. One advantage of leptin is without to gain weight in the treatment of type 1 DM while making a balance of blood glucose. An extensive research report that type 1 DM reduces body weight $[11,23]$ as reported in the present study. It is probably that type 1 DM causes dehydration, declining glucose utilisation and protein anabolism [10]. Leptin provides a link between body weight and food intake $[5,49]$. A correlation between serum leptin levels, plasma insulin, and body mass index has been reported [49]. Leptin in high concentrations causes insulin resistance [49]. In the present study, diabetic rats lose the body weight as stated in the previous study [9]. While leptin treatment seems to be protective, it was considered that weight gain in leptin-treated groups looks like developing type $2 \mathrm{DM}$ as was explained in below. Leptin antagonizes the effect of insulin on glucokinase and phosphoenolpyruvate carboxylase enzymes to decrease blood glucose levels in the liver. A decrease in leptin efficiency is related to insulin resistance in type 2 DM [36]. Insulin secretion occurs in two phases. One phase called fast secretion requires glucose entry to the $\beta$-cells, and this leads to the closure of ATP sensitive potassium channel $\left(\mathrm{K}_{\mathrm{ATP}}\right)$ resulting in depolarisation [8]. Finally, insulin secretion occurs. The second phase is essential to maintain the insulin level in plasma [8]. This phase is associated with the reserved pool, which is far away from the plasma membrane [12]. Reserved insulin granules must be transported to the plasma membrane [8]. F-actin is vital to maintaining basal plasma insulin levels [22]. Therefore, actin cytoskeleton plays a significant role in both phases of insulin secretion [12]. In the current study, diabetes caused a decrease of G-actin, while any effect was observed on F-actin in vivo. This effect can be explained that glucose enhances F- or G-actin ratio which means that hyperglycaemia can inhibit G-actin disassociation by partial stimulation of cofilin phosphorylation. Cofilin belongs to one of actindepolymerising factor family and can be inactivated with phosphorylation by LIM kinase, causing F-actin stabilisation [19]. Rho-A could participate in this pathway [48]. Diabetes is well known as an autoimmune disease. Macrophages inhibit Rho pathways caused to disrupt of the cytoskeleton from subcortical actin ring to near the cell periphery [13]. G-actin is needed for F-actin resembling. Therefore; F-actin maintains its proper function. It was proposed that attenuation of G-actin participate in the development of diabetes.

Furthermore, F-actin reorientation was observed the at the plasma membrane surrounding in the current study. F-actin can be depolymerised and scavenged by the action of gelsolin, which is one of the free calcium regulators, resulting in blood glucose attenuation via the blockage of insulin vesicle transport to the membrane [10]. It was suggested that a high plasma glucose level could induce actin cytoskeleton disruption [22]. This is asserted to relate apoptotic cell death [25]. That is why F-actin could release from cell to plasma when cell injury is occurred [10]. Leptin is also reported to activate LIM kinase for phosphorylation of cofilin, resulting in accumulation F-actin and depletion of G-actin. The other effect of leptin on actin is up-regulation of alpha-skeletal actin and myosin light chain-2 (MLC-2) [16].

Insulin and leptin have anti-apoptotic and proliferative effects [39]. Furthermore, leptin was shown to have a positive impact on glucose metabolism, and it was an excellent adjuvant candidate for insulin therapy [44]. Leptin enhanced the insulin sensitivity in rats with type $2 \mathrm{DM}$ and patients with type 2 as well. A single administration of leptin ameliorated the mortality related to high blood glucose and insulin independent insulin deficiency [15]. Leptin is shown 
its anti-diabetic effect via increasing insulin receptor sensitivity. However, the involvement of F-actin in the mechanism of leptin on type-1 DM is not clearly evaluated. Diabetes and leptin therapy showed their destructive effect on F-actin according to cell type in the current study in vitro. F-actin disappeared from cytosol center and accumulated within the periphery of the cell membrane in primary parenchymal cells.

On the contrary, F-actin clustered within the cytosol center as multicentered radiant groups in Kupper primary cells. In primary pancreas cells, the destruction process in actin filament is similar to Kuppfer primary cell. It was shown that leptin binding to its receptor (Ob-Rb) phosphorylates JAK2 and transforms $\mathrm{PIP}_{2}$ into $\mathrm{PIP}_{3}$. This destroys the F-actin into the G-actin [18]. One study is reported that RhoA and ROCK are mediated leptins effect on F-actin distribution. Leptin is suggested to enhance the expression and activities of GLUT2 and GLUT5 transporters [30]. Leptin has been reported to improve insulin sensitivity in both healthy and diabetic animals. However, the hormone is also said to destroy insulin effect on hepatocytes. Leptin infusion is an essential factor for disclosing its effect on tissue. Leptin is suggested to decrease blood glucose and insulin level without altering body weight of animals by subcutan infusion. Leptin intravenously injection boosts inulin sensitivity in healthy animals, increase glucose consumption in diabetic animals. STZ destroy pancreatic $\beta$-cell and decrease adipose and plasma leptin levels. Therefore, leptin therapy can mimic insulin action by insulin-independent and an insulin-sensitising mechanism in STZ treated animals. Leptin has been shown to activate $\mathrm{K}_{\mathrm{ATP}}$, resulting in decreasing insulin secretion [3].

Cell skeleton is a dynamic and sensitive system. It is pointed out as an important morphologic parameter in the study of changes that took place in the cell after getting into reaction with substance [29]. Some vesication is formed within the whole cell during the process of cell skeleton's restructuring. This incidence of vesication that took place outside the cell goes along both with the distribution of microtubules [45] and actin filaments' restructuring. Actin polymerisation occurs at $\mathrm{G} 1$ and $\mathrm{G} 2 / \mathrm{M}$ phases of the cell cycle [32]. In actin polymerisation, F- or G-actin rates show cellular separation (differentiation) [32].

\section{CONCLUSIONS}

The in vivo protective effect of leptin treatment on the F-actin structure in both liver and pancreas tissues has been presented in the current study. However, leptin could not significantly improve F-actin orientation in vitro in different cell types. A slight improvement of F-actin orientation was observed in Kupffer cells compared to parenchymas. Leptin at the higher doses can contribute to the destructive effects of diabetes. Filopodia formation can be reversed by leptin treatment without changing the F-actin destruction according to the severity of diabetic conditions. In conclusion, leptin treatment could be useful when the severity of diabetes and leptin doses are taken into consideration.

\section{Acknowledgements}

This study was supported by the Istanbul University Research Fund for (Project No: 8903).

\section{REFERENCES}

1. Arous $C$, Halban P. The skeleton in the closet: actin cytoskeletal remodeling in $\beta$-cell function. Am J Physiol Endocrinol Metab. 2015; 309(7): E611-E620, doi: 10.1152/ ajpendo.00268.2015.

2. Beale EG. Insulin signaling and insulin resistance. J Investig Med. 2013; 61(1): 11-14, doi: 10.2310/ JIM.0b013e3182746f95, indexed in Pubmed: 23111650.

3. Ceddia RB, Koistinen HA, Zierath JR. Analysis of paradoxical observations on the association between leptin and insulin resistance. Faseb J. 2002; 16: 1163-1176.

4. Chen PC, Kryukova YN, Shyng SL. Leptin regulates KATP channel trafficking in pancreatic $\beta$-cells by a signaling mechanism involving AMP-activated protein kinase (AMPK) and CAMP-dependent protein kinase (PKA). J Biol Chem. 2013; 288(47): 34098-34109, doi: 10.1074/jbc. M113.516880, indexed in Pubmed: 24100028.

5. Considine $R$, Sinha $M$, Heiman $M$, et al. Serum immunoreactive-leptin concentrations in normal-weight and obese humans. N Engl J Med. 1996; 334(5): 292-295, doi: 10.1056/nejm199602013340503.

6. Cortés VA, Cautivo KM, Rong S. Leptin ameliorates insulin resistance and hepatic steatosis in Agpat2(-/-) lipodystrophic mice independent of hepatocyte leptin receptors. J Lipid Res. 2014; 55: 276-288.

7. Coupe B, Grit I, Hulin P. Postnatal growth after intrauterine growth restriction alters central leptin signal and energy homeostasis. PLoS One. 2012; 7: e30616.

8. Dehghany J, Hoboth P, Ivanova A, et al. A Spatial Model of Insulin-Granule Dynamics in Pancreatic $\beta$-Cells. Traffic. 2015; 16(8): 797-813, doi: 10.1111/tra.12286, indexed in Pubmed: 25809669.

9. Denroche H, Quong W, Bruin J, et al. Leptin administration enhances islet transplant performance in diabetic mice. Diabetes. 2013; 62(8): 2738-2746, doi: 10.2337/ db12-1684.

10. Dominguez R, Holmes KC. Actin structure and function. Annu Rev Biophys. 2011; 40: 169-186, doi: 10.1146/ annurev-biophys-042910-155359, indexed in Pubmed: 21314430. 
11. Emekli-Alturfan E, Kasikci E, Yarat A. Tissue factor activities of streptozotocin induced diabetic rat tissues and the effect of peanut consumption. Diabetes Metab Res Rev. 2007; 23(8): 653-658, doi: 10.1002/dmrr.757, indexed in Pubmed: 17595667

12. Fan F, Ji C, Wu Y, et al. Dynamin 2 regulates biphasic insulin secretion and plasma glucose homeostasis. J Clin Invest. 2015; 125(11): 4026-4041, doi: 10.1172/jci80652.

13. Fan $\mathrm{H}$, Patel VA, Longacre A. J.S. Levine, Abnormal regulation of the cytoskeletal regulator Rho typifies macrophages of the major murine models of spontaneous autoimmunity, J Leukoc Biol. 2006; 79: 155-165.

14. Fofana $B$, Yao XH, Rampitsch $C$, et al. Prenatal alcohol exposure alters phosphorylation and glycosylation of proteins in rat offspring liver. Proteomics. 2010; 10(3): 417-434, doi: 10.1002/pmic.200800969.

15. Fujikawa T, Chuang JC, Sakata I, et al. Leptin therapy improves insulin-deficient type 1 diabetes by CNSdependent mechanisms in mice. Proc National Academy Scien. 2010; 107(40): 17391-17396, doi: 10.1073/ pnas. 1008025107.

16. Ghantous CM, Azrak Z, Hanache S. Differential Role of Leptin and Adiponectin in Cardiovascular System. Int J Endocrinol. 2015; 2015: 534320.

17. Guven C. The effect of Diazoxide on norepinephrineinduced cardiac hypertrophy, in vitro. Cell Mol Biol (Noisy-le-grand). 2018; 64(10): 50-54, doi: 10.14715/ $\mathrm{cmb} / 2018.64 .10 .8$.

18. Harvey J, Ashford ML. Leptin in the CNS: much more than a satiety signal. Neuropharmacology. 2003; 44(7): 845-854, indexed in Pubmed: 12726816.

19. Hien TT, Turczyńska KM, Dahan D, et al. Elevated glucose levels promote contractile and cytoskeletal gene expression in vascular smooth muscle via rho/protein kinase c and actin polymerization. J Biol Chem. 2016; 291(7): 3552-3568, doi: 10.1074/jbc.M115.654384, indexed in Pubmed: 26683376.

20. Ishii S, Kamegai J, Tamura H, et al. Role of ghrelin in streptozotocin-induced diabetic hyperphagia. Endocrinology. 2002; 143(12): 4934-4937, doi: 10.1210/en.2002-220612.

21. Justice JD, Brannon PM. Synthesis of amylase by cultured rat pancreatic acinar cells: effects of antecedent diet J Nutr. 1989; 119(5): 805-812, doi: 10.1093/jn/119.5.805, indexed in Pubmed: 2470881.

22. Kalwat MA, Thurmond DC. Signaling mechanisms of glucose-induced F-actin remodeling in pancreatic islet $\beta$ cells. Exp Mol Med. 2013; 45: e37, doi: 10.1038/emm.2013.73, indexed in Pubmed: 23969997.

23. Kaya ST, Bozdogan O, Ozarslan TO, et al. The protection of resveratrol and its combination with glibenclamide, but not berberine on the diabetic hearts against reperfusion-induced arrhythmias: the role of myocardial K channel. Arch Physiol Biochem. 2019; 125(2): 114-121, doi: 10.1080/13813455.2018.1440409, indexed in Pubmed: 29457517

24. Kelesidis T, Kelesidis I, Chou S. Narrative review: the role of leptin in human physiology: emerging clinical applications. Ann Internal Med. 2010; 152: 93-100.

25. Khatri N, Sagar A, Peddada N, et al. Plasma gelsolin levels decrease in diabetic state and increase upon treatment with F-actin depolymerizing versions of gelsolin. J Diabetes
Res. 2014; 2014: 152075, doi: 10.1155/2014/152075, indexed in Pubmed: 25478578.

26. Kim HR, Gallant C, Leavis PC. Cytoskeletal remodeling in differentiated vascular smooth muscle is actin isoform dependent and stimulus dependent. Am J Physiol Cell Physiol. 2008; 295: C768-C778.

27. King $A$. The use of animal models in diabetes research. $\mathrm{Br}$ J Pharmacol. 2012; 166(3): 877-894, doi: 10.1111/j.14765381.2012.01911.x.

28. Klaunig J, Goldblatt $P$, Hinton $D$, et al. Mouse liver cell culture. In Vitro. 1981; 17(10): 926-934, doi: 10.1007/bf02618289.

29. Kohler M, Aufderheide M, Ramm D. Method for the description of differences in the filamentous structure of the cytoskeleton in cultured cells. Toxicol Lett. 1994; 72(1-3): 33-42, indexed in Pubmed: 8202948.

30. Le Drean G, Segain JP. Connecting metabolism to intestinal barrier function: The role of leptin. Tissue Barriers. 2014; 2: e970940.

31. Londoño M, Tellez L, Gutierrez R. Physiological low doses of leptin and cholecystokinin induces body weight-loss in juvenile and lean, but not in adult-obese rats. Int J Peptide Res Therap. 2011; 18(1): 77-88, doi: 10.1007/ s10989-011-9281-9.

32. Lu QY, Jin YS, Zhang Q, et al. Ganoderma lucidum extracts inhibit growth and induce actin polymerization in bladder cancer cells in vitro. Cancer Lett. 2004; 216(1): 9-20, doi: 10.1016/j.canlet.2004.06.022, indexed in Pubmed: 15500944

33. Maria Z, Yin W, Rubenstein DA. Combined effects of physiologically relevant disturbed wall shear stress and glycated albumin on endothelial cell functions associated with inflammation, thrombosis and cytoskeletal dynamics. J Diabetes Investig. 2014; 5(4): 372-381, doi: 10.1111/ jdi.12162, indexed in Pubmed: 25411596.

34. Marroqui L, Gonzalez A, Neco P. Role of leptin in the pancreatic beta-cell: effects and signaling pathways. J Molec Endocrinol. 2012; 49: R9-17.

35. Millioni R, lori E, Puricelli L, et al. Abnormal cytoskeletal protein expression in cultured skin fibroblasts from type 1 diabetes mellitus patients with nephropathy: a proteomic approach. Proteomics Clin Appl. 2008; 2(4): 492-503, doi: 10.1002/prca.200780112, indexed in Pubmed: 21136853.

36. Moon HS, Dalamaga M, Kim SY, et al. Leptin's role in lipodystrophic and nonlipodystrophic insulin-resistant and diabetic individuals. Endocrine Rev. 2013; 34(3): 377-412, doi: 10.1210/er.2012-1053.

37. Naito M, Fujikura J, Ebihara K, et al. Therapeutic impact of leptin on diabetes, diabetic complications, and longevity in insulin-deficient diabetic mice. Diabetes. 2011; 60(9): 2265-2273, doi: 10.2337/db10-1795, indexed in Pubmed: 21810600.

38. Paz-Filho G, Mastronardi C, Wong ML, et al. Leptin therapy, insulin sensitivity, and glucose homeostasis. Indian J Endocrinol Metab. 2012; 16(9): 549-555, doi: 10.4103/22308210.105571.

39. Rubenstein JH, Morgenstern H, McConell D, et al. Associations of diabetes mellitus, insulin, leptin, and ghrelin with gastroesophageal reflux and Barrett's esophagus. Gastroenterology. 2013; 145(6): 1237-12344.e1, doi: 10.1053/j. gastro.2013.08.052, indexed in Pubmed: 23999171. 
40. Sah S, Singh B, Choudhary S, et al. Animal models of insulin resistance: A review. Pharmacological Reports. 2016; 68(6): 1165-1177, doi: 10.1016/j.pharep.2016.07.010.

41. Shoji T, Nishizawa $Y$, Emoto $M$, et al. Renal function and insulin resistance as determinants of plasma leptin levels in patients with NIDDM. Diabetologia. 1997; 40(6): 676-679, doi: 10.1007/s001250050733, indexed in Pubmed: 9222647.

42. Soetikno V, Sari FR, Veeraveedu PT, et al. Curcumin ameliorates macrophage infiltration by inhibiting NF- $\kappa \mathrm{B}$ activation and proinflammatory cytokines in streptozotocin induced-diabetic nephropathy. Nutr Metab (Lond). 2011; 8(1): 35, doi: 10.1186/1743-7075-8-35, indexed in Pubmed: 21663638

43. Trevelin SC, Carlos D, Beretta M, et al. Diabetes mellitus and sepsis: A Challenging Association. Shock. 2017; 47(3): 276-287, doi: 10.1097/SHK.0000000000000778, indexed in Pubmed: 27787406.

44. Tucholski K, Otto-Buczkowska E. The role of leptin in the regulation of carbohydrate metabolism. Endokrynol Pol. 2011; 62: 258-262.

45. Uzdensky A, Kolpakova E, Juzeniene A, et al. The effect of sub-lethal ALA-PDT on the cytoskeleton and adhesion of cultured human cancer cells. Biochim Biophys Acta. 2005; 1722(1): 43-50, doi: 10.1016/j.bbagen.2004.11.011.
46. Visa N, Percipalle P. Nuclear functions of actin. Cold Spring Harb Perspect Biol. 2010; 2(4): a000620, doi: 10.1101/ cshperspect.a000620, indexed in Pubmed: 20452941.

47. Wagoner B, Hausman DB, Harris RBS. Direct and indirect effects of leptin on preadipocyte proliferation and differentiation. Am J Physiol Regul Integr Comp Physiol. 2006; 290(6): R1557-R1564, doi: 10.1152/ajpregu.00860.2005, indexed in Pubmed: 16424081.

48. Wang $X$, Tang P, Guo F, et al. RhoA regulates Activin $B$-induced stress fiber formation and migration of bone marrow-derived mesenchymal stromal cell through distinct signaling. Biochim Biophys Acta Gen Subj. 2017; 1861(1 Pt A): 3011-3018, doi: 10.1016/j.bbagen.2016.09.027, indexed in Pubmed: 27693126.

49. Widjaja A, Stratton IM, Horn R, et al. UKPDS 20: plasma leptin, obesity, and plasma insulin in type 2 diabetic subjects. J Clin Endocrinol Metab. 1997; 82(2): 654-657, doi: 10.1210/jc.82.2.654.

50. Yu M, Yuan X, Lu C, et al. mDia1 senses both force and torque during F-actin filament polymerization. Nature Communications. 2017; 8: 1650.

51. Zhu X, Hu R, Brissova M, et al. Microtubules negatively regulate insulin secretion in pancreatic $\beta$ cells. Developmental Cell. 2015; 34(6): 656-668, doi: 10.1016/j. devcel.2015.08.020. 